Tarih Kültür ve Sanat Araştırmaları Dergisi

Revue des Recherches en Histoire Culture et Art

$$
\text { مجلة البحوث التاريخية و الثقافية والفنية }
$$

Vol. 6, No. 5, November 2017

Copyright (C) Karabuk University

http://kutaksam.karabuk.edu.tr

\title{
DOI: 10.7596/taksad.v6i5.1279
}

Citation: Guseinova, A., \& Zayni, R. (2017). Essay Genre in Tatar Journalism. Journal of History Culture and Art Research, 6(5), 397-402. doi:http://dx.doi.org/10.7596/taksad.v6i5.1279

\section{Essay Genre in Tatar Journalism}

\author{
Aigul A. Guseinova ${ }^{1}$, Rezeda L. Zayni ${ }^{2}$
}

\begin{abstract}
In this article, an essay is considered as a journalistic genre in the context of modern Tatar journalism. Using the example of works by contemporary authors in the Tatar-speaking periodicals of Russia, the main genre and the semantic features of this genre are studied. An essay is a publicistic form to reflect on the topical issues of Russian reality. The reproduction of a fact is not so important for an essay. An important role is played by the description of the author's impressions, reflections and emotions. The periodical press has many materials in the Tatar language in which the author's opinion, author's principle and subjective opinion are strongly expressed. In fact, during the last decades of the twentieth century and the beginning of the twenty-first century there was a surge of essays in modern journalism. Due to some political events in Russia during the early 90s of the twentieth century, it was possible to express their thoughts and speak on the urgent problems in society openly in comparison with the Soviet reality. The object of research is essayism as a kind of journalistic creativity, the subject of the study is the essay genre in Tatar journalism. The empirical basis of the work consisted of the essays from Tatar journalists, publicists and writers. Provided that the personality of an author is one of the effectiveness factors concerning the publications in the genre of essay, the essayization of texts in Tatar journalism will be increased in the future.
\end{abstract}

Keywords: Tatar journalism, Journalistic genres, Genre, Essay, Periodicals.

\footnotetext{
${ }^{1}$ Kazan Federal University, Kremliovskaya str, 18, 420008, Kazan, Russian Federation. E-mail: agusejno@kpfu.ru

${ }^{2}$ Kazan Federal University, Kremliovskaya str, 18, 420008, Kazan, Russian Federation.
} 


\section{Introduction}

The obligatory genres are characteristic for periodical printing in Tatar, like in any language. First of all, notes, reports, interviews, correspondence, articles, reviews and essays are used.

What is the interest in the genre of an essay for a reader and what are his prospects? Let's begin with the fact that in modern journalism serious analysts are gradually being pushed into the background. A reader is an active inhabitant of a megacity or a rural area, there is no difference, he does not like to spend a lot of time with a newspaper or a magazine. He needs maximum of information, but with minimum of text. In such conditions, journalists learn to write briefly, presenting only the essence of the problem, but without revealing and, especially, without thinking about it and without offering the possible ways for solution. Voluminous articles are written rarely and for a certain audience. At the same time, a reader wants to hear an opinion from a journalist, his opinion is important to him, his evaluation of events is necessary. Then the authors turn to the genre of an essay, which provides a great opportunity for one's own opinion expression, where the subjective component comes to the forefront.

\section{Methods}

Based on the nature of the material being studied and the aims of the work, the descriptive, comparative, historical-comparative methods widely used in philology were applied.

\section{Discussion}

The theoretical and methodological basis for the study was represented by the works of foreign (Huxley, 1959; Mersand, 1968; Chadbourne, 1983; Hyland, 1990) and domestic (Dmitrovsky, 2002; Durova, 2000; Nizamov, 2008) scholars. When they study the essays as a kind of journalistic creativity, the empirical basis of the work was composed of the essays by Tatar journalists, publicists and writers. Their choice was determined by certain criteria. First of all, we settled on the generally accepted examples of essays in Tatar journalism. Secondly, they analyzed the works of different years, from 1990 to 2016, because since it is necessary to take into account historical experience to establish all the characteristics of the genre. Thirdly, the materials in the genre of essays were studied by different authors, taking into account their creative features.

The materials in the genre of essays are published under special headings in newspapers and magazines: the newspaper "Mydayni Komga" ("Cultural Friday") - the heading is "I said", "Vatanym Tatarstan" (Republic of Tatarstan) - "The Voice of Soul", the newspaper "Shari Kazan" (Evening Kazan) - "The Word of the Publicist"; the magazine "Kazan utlary" (Lights of Kazan) - "Publicism", "Idel" (Idel) - "Memory. Memoirs", "Веzneң miras" (Our heritage) - "From the depths of memory", etc.

In the 80-90s of the 20th century, the concept of "essay" is used in journalistic materials of Tatar newspapers and magazines. Essay was represented mainly by documentary works, memoirs, travel notes, the reflections of famous writers and publicists. For the first time in the theory of Tatar journalism genres, the notion of an essay as a separate independent genre is introduced by a well-known scholar Gazi Kashshaf (Nizamov, 2008).

In French, the word "essay" means an attempt, an experience, a sketch, a test, and it comes from the Latin exagium - weighing. Aldous Huxley, being the leading essayist, writes the following about this genre: "The essay is a literary device for saying almost everything about almost anything" (Huxley, 1959). The genre of essay is traditionally considered by scholars in the Western and the Eastern versions. The Western essay is characterized by rationality, sociocentricity, and the eastern one is characterized by the comprehension of emotional harmony (Buzalskaya, 2015). 
It is believed that the genre of essay was not recognized during the Soviet period and until the 1970s and 1980 s it was extremely rare. It was considered as the equivalent of other genres - a treatise, a diary, an article (Baybatyrova, 2012: 82).

The genre of essay is quite widespread in Tatar journalism. It belongs to the group of literary and journalistic genres. This group can be considered in two conditional subgroups. The first includes sketch genres (actually an essay itself, a sketch, a miniature), the second group includes satirical genres (a feuilleton, a pamphlet, an anecdote).

An essay can be considered as a prose essay. In most cases, it refers to a specific subject or an event in general. An author of an essay should not only know a topic well, a personal experience and a strong base of logical and philosophical thinking are required.

Previously, an essay was a part of literary genre system for the reason that it was based on a description of feelings, emotions, the emotions inherent to an individual, an author. At the same time, an essay is characterized by analysis, it strongly emphasizes the author's position and an essay is based on events of reality. For this reason, an essay is referred to artistic and journalistic genre in the modern theory of journalism.

We managed to single out three basic models of an essay in the Tatar periodical press: literary, philosophical, scientific and journalistic one. You can also find the forms of academic and official-business essay. For example, in the newspaper "Mədəni жomga" (Cultural Friday) the academic essays of students from the Kazan Federal University were published for a long time concerning the role of the native language in the development of society.

Even philosophical and scientific essays on style differ from other publications in their imagery, aphoristic means and individuality.

1. Literary essay. It is inherently a critical material that is based not on the analysis of events, but on a subjective author's assessment.

2. Philosophical essay. The reflections about life, death, reality are based on it.

3. Scientific and journalistic essay. Very similar to an essay, but if the essence of an essay is determined by facts, documentary nature, then they are not necessary for essays, because the main thing for an essay is the author's thoughts and reflections inherent only to him.

In journalism, an essay is a special genre, similar to an article or a note, it consists of the author's philosophical reflections entirely. The author's "I" distinguishes it from other genres.

The following features are inherent for an essay in Tatar:

1. Heroes and events, the problems in an essay are not fictional.

2. The description of characters, events, problems occurs through personal experience, through an author's personal opinion. An author knows his characters, he communicated with them.

3. The focus of an essay is a specific topic and a specific problem. The analysis of a wide range of problems can not be performed in the genre of an essay.

4. An author can rely on someone else's opinion, but draws his own conclusions.

5. An author's "I" is clearly expressed: an author gives examples from his experience, uses the pronoun "I", the speech is from the first person.

6. An essay is characterized by a free composition, it does not tolerate limits and boundaries. Narrative is fascinating and interesting for a reader. 


\section{Results}

An essay as a genre received special development in the Tatar journalism during the last decades, although some of its signs as a genre can be traced in the works of Tatar literature and journalism of the previous centuries.

Let's denote the main themes inherent to an essay in modern Tatar journalism:

1) philosophical reflections on the national consciousness, on the struggle for national self-determination of the Tatar nation, on the attitudes towards political events;

2) the speeches concerning the issues of Russian society development: the role and the place of national languages in Russia, religion, Russian federalism, the correct attitude to the history of the country as a whole and the Tatar people in particular, moral education, ecological status, etc.;

3) the reflections and memories of outstanding personalities. This includes autobiographical works;

4) scientific or professional essays.

Even with a serious scientific, scientific-popular, social-political content, an essay is characterized by imagery, aphorism, and also an author's individuality is expressed.

Essentially, an essay always requires a response from a reader, because an author's reflections force to reflect and express themselves, and the artistic quality of an essay text also adds emotions, thus inducing to a dialogue.

As you know, an essay is an artistic and journalistic genre, which is at the crossroads of literature, journalism and science. The features of an essay genre, and its popularity in the modern Tatar press will be considered using the example of two magazines - "Idel" (the name from the Volga River, which flows through the territory of Tatarstan) and "Веzneң miras" (Our heritage). "Idel" is the magazine for young people, it is published once a month in Tatar and Russian languages since 1989, and "Bezney miras" is a monthly popular scientific, literary and art journal is published in Tatar language. It should be noted that the magazine rebranded the name: the magazine "Miras" (Heritage) issued since April 1991, has been revived with the new name and content of "Chyn miras" ("The Present Heritage") since May of 2012 according to the decision of the founder - the joint-stock company "Tatmedia", and later, in 2014, it became known as "Веznең miras".

If the journal "Idel" mainly publishes young talents, the authors of the journal "Веzneң miras" are venerable scientists, writers, and publicists. Using the example of their works, you can submit materials in the genre of essays. It is interesting that the authors often call them stories, legends, etc.

For example, the journalistic material titled as "Where is a sledge?" by the young publicist Aigul Abdrakhmanova (Idel, 2015, No. 10, pp. 7-8) is essentially an essay. A well-known Tatar poet Rkail Zaydulla calls his poem "The flexible stick" "kyissa" (a poem, a legend, a biography), but this is also an essay where the author shares his impressions and memories of the first days in school (Idel, 2015, No. 11, pp. 66-67). The next publication can be called a problematic essay: the author of the material "The Sense of the family nest" Faiz Zulkarnai, the Tatar poet and writer, reflects through the image of the patrimonial home about the preservation of the Tatar language, the mentality of the Tatars as a nation and the Tatar culture, about the mixed marriages between Tatars and Russians, etc. (Idel, 2016, No. 12, pp. 22-24).

The magazine "Веzneң miras" differs quite clearly from the previous one on the topic and the presentation of materials, the materials in the genre of essays have their own form in it. For example, under the heading "The Word and the Image" the authors share their memories of those people whose 
photos are placed on a page of the magazine practically in each issue of the magazine. They do not just share information when and under what circumstances these pictures were taken, but also reflect and share their impressions of them. The poet Radif Gatash writes about his contemporaries-writers and about their common train to Kazakhstan (Веzneң miraz, No. 10, pp. 34-35). In another issue of the magazine, the well-known composer Masgut Imashev recalls the People's Artist of Tatarstan Lucia Farsina (Bezney miras, 2015, No. 11, pp.58-59). The memories from the wife of the Professor, the Doctor of historical sciences Faizelhak Islaev are very touching (Вezneң miraz, 2015, No. 12, pp. 60-61). A short essay on the beginning of the famous Kamala Theater construction in Kazan tells about those enthusiasts who started this work on volunteer basis (Веzneң miraz, 2016, No. 12, p. 90).

And finally, in the philosophical essay "How does Tatar music appear?!" the musicologist Mars Makarov reflects on music and seeks for the answers to the question of where a melody is born in Tatar songs, where does the word "mon" come from (the word from the Tatar language cannot be translated directly, only approximate meaning can be given - "a melody", "music", "a sound"). The author remembers the great Tatar composers, singers and musicians in the essay (Bezneң miras, 2015, No. 9, pp. 108-109).

\section{Conclusion}

On the basis of the obtained data, we found that the essays examined by us have an evaluation vocabulary, which has a strong emotional color, it is aimed at a conversation with a reader, i.e. a dialogue is clearly visible. The essay informs and explains the meaning of an event, a phenomenon, a being, but does not depict or retell them. After all, an essay does not require fiction and a complex dramatic plot, because it affects a reader in a different way, combining the private, the individual and general, social, being, comprehending all that attracts the attention of its author. Hence the conclusion that an essay as a genre is aimed at the revealing of an author's inner creative potential.

If journalism had a fact in the first place before, now the opinion comes to the forefront. An author's opinion is important for a reader, but not an opinion of any author, but of a publicist, a trusted journalist, writer, politician, sociologist, etc. In short, an author's personality is one of the factors of the material efficiency in the genre of the essay. In this regard, we see the prospect of an increasing essayization of texts in Tatar journalism. The genre of an essay, for which both the objectivity of facts and an author's subjectivity are characteristic, will remain relevant in the covering social and political events that are significant for an audience.

\section{Acknowledgements}

The work is performed according to the Russian Government Program of Competitive Growth of Kazan Federal University.

\section{References}

Baybatyrova, N. M. (2012). An essay genre in the journalism of the Russian emigrants of the second half of the twentieth century. Problems of modern science and education, 12(12), 82-83.

Buzalskaya, E. V. (2015). Essays: to the history of genre formation. The world of the Russian word, 2, 3641. 
Chadbourne, R. M. (1983). A puzzling literary genre: comparative views of the essay. Comparative literature studies, 20(2), 133-153.

Dmitrovsky, L. D. (2002). Essay as the genre of publicism. The dissertation of the Doctor of Philology: 10.01.10. St. Petersburg.

Durova, O. I. (2000). The Norwegian essay of 1960s-1990s: Poetics, problematics, gnoseological prospects of a genre. The dissertation of the Doctor of Philology: 10.01.10. Krasnodar.

Huxley, A. (1959). Collected essays. New York: Harper.

Hyland, K. (1990). A genre description of the argumentative essay. RELC Journal, 21(1), 66-78.

Mersand, J. (ed.) (1968). Great Narrative Essays. New York: Washington Square Press.

Nizamov, I. M. (2008). Gazi Kashshaf is a writer-journalist, teacher, scholar. Essay and note. Kazan. Kazan State University. 